\title{
ARGUMENTASI SYEKH NAWAWI BIN UMAR AL-BANTANI TENTANG KEDUDUKAN PEREMPUAN DALAM KELUARGA KAJIAN FIQH KESETARAAN
}

\author{
Widiyarti \\ IAIN Ponorogo \\ widiyartiyuliana@gmail.com \\ Rohmah Maulidia \\ IAIN Ponorogo \\ rahmahmaulidia77@gmail.com
}

\begin{abstract}
:
The behavior of human life can not be separated from its perspective on a concept or thought that it believes in. This study aims to explore thougts and arguments of Sheikh Nawawi and then analyze them in the framework of gender equality and Mubadalah relations in the life of husband and wife. Textually, behalf on Uqudullujain, explains that the position of woman is not equal to the man. The husband is allowed to beat his wife if the wife does not carry out the husband's order, especially to make up and preen, refuse to be invited to sleep together, and the wife is also not allowed to ask for a divorce.
\end{abstract}

Keyword: Gender, equality, woman

\begin{abstract}
Abstrak:
Perilaku kehidupan manusia tidak dapat terlepas dari cara pandangnya terhadap sebuah konsep atau pemikiran yang diyakininya. Tulisan ini mengekplorasi pemikiran dan argumentasi Syekh Nawawi kemudian menganalisisnya dalam bingkai kesetaraan gender dan relasi mubadalah dalam kehidupan suami istri. Secara tekstual, kitab Uqudullijain menjelaskan kedudukan perempuan tidak setara dengan laki-laki. Suami diperkenankan memukul istri, jika istri tidak mengindahkan perintahnya untuk berhias dan bersolek, menolak diajak tidur bersama, serta istri juga tidak diperkenankan meminta cerai.
\end{abstract}

Kata Kunci: Gender, kesetaraan, perempuan

\section{PENDAHULUAN}

Kedudukan manusia, baik laki-laki maupun perempuan sangatlah mulia di hadapan Allah Swt. Bahkan Nabi mewasiatkan penghormatan pada perempuan dalam haji wada'. Namun tidak sedikit orang yang merendahkan perempuan, dan masih menganggapnya makhluk kelas dua. Minimnya penghormatan dan penghargaan kepada perempuan serta relasi yang timpang masih terjadi di Indonesia. Bahkah tidak sedikit perempuan menjadi korban kekerasan. Baik kekerasan fisik maupun kekerasan psikologis.

Data dari Kementerian Pemberdayaan Perempuan dan Anak menyebutkan, terdapat 299.911 kasus mengenai kekerasan terhadap perempuan. Diantara kasus tersebut, sejumlah 291.677 kasus ditangani oleh pengadilan, sejumlah 8.234 kasus 


\section{0 | Argumentasi Syekh Nawawi bin Umar Al-Bantani}

ditangani oleh Lembaga layanan mitra Komnas Perempuan, dan sebanyak 2.389 kasus ditangani Unit Pelayanan dan Rujukan (UPR) Komnas Perempuan. Dari kasus yang ditangani oleh lembaga layanan mitra Komnas Perempuan, diantaranya yaitu kekerasan terhadap istri (KTI) menempati peringkat pertama, kekerasan dalam pacaran menempati peringkat kedua, kekerasan terhadap anak perempuan menempati peringkat ketiga, dan sisanya berupa kekerasan yang dilakukan mantan pacar, mantan suami, serta kekerasan terhadap pekerja rumah tangga. Bentuk kekerasan yang paling menonjol di ranah pribadi ini adalah kekerasan fisik menempati peringkat pertama disusul kekerasan seksual, psikis, dan ekonomi. ${ }^{1}$

Mengapa perempuan masih menjadi korban kekerasan. Beberapa literatur menyebutkan kekerasan muncul disebabkan oleh masalah ekonomi, perselingkuhan, campur tangan pihak ketiga, bermain judi, budaya patriarki, dan perbedaan prinsip. Bentuk-bentuk kekerasan, yang pada umumnya dialami oleh survivor ${ }^{2}$ adalah kekerasan fisik ( diantaranya adalah ditampar, ditempeleng, dijambak, dan diinjakinjak), kekerasan psikis (yaitu dicaci maki, dan diancam), serta penelantaran rumah tangga. Mirisnya, sebagian besar survivor memilih untuk diam atas kekerasan yang menimpanya. Dan masih sedikit diantara survivor yang melawan atas kekerasan yang menimpanya. Padahal, perlawanan tersebut merupakan upaya perlindungan atas kekerasan yang mengakibatkan luka fisik maupun nonfisik. ${ }^{3}$

Berbagai upaya mengakhiri kekerasan telah dilakukan. Baik melalui pencegahan dan lembaga advokasi yang didirikan oleh masyarakat. Upaya pencegahan juga dilakukan melalui kritik teks dan wacana yang disuarakan oleh agamawan dan ilmuwan. Dengan cara menafsir ulang terhadap teks yang bernada misoginis dan patriarkis yang beredar di masyarakat luas.

Dalam tulisan ini akan dibahas tentang pemikiran Syekh Nawawi dengan pendekatan teori kesetaraan dan ketersalingan (mubadalah). ${ }^{4}$ Terlebih dahulu akan dipaparkan biografi singkat Syekh Nawawi, karya-karya beliau dan pemikirannya dalam kitab Uqudullijain. Kemudian akan dianalisis menggunakan teori kesetaraan gender dan teori mubadalah.

\footnotetext{
1 Https://Nasional.Tempo.Co/Read/1439271/Komnas-Perempuan-Ada-299-911-KasusKekerasan-Terhadap-Perempuan-Sepanjang-2020/Full\&View=Ok

Istilah Survivor iini digunakan evi tri dalam risetnya.

Evi Tri Jayanthi, "Faktor-Faktor Penyebab Terjadinya Kekerasan Dalam Rumah Tangga Pada Survivor Yang Ditangani Oleh Lembaga Sahabat Perempuan Magelang," Dimensia, Volume 3, No. 2, September 2009, 33: Baca Juga Mery Ramadani1 Dan Fitri Yuliani, "Kekerasan Dalam Rumah Tangga (Kdrt) Sebagai Salah Satu Isu Kesehatan Masyarakat Secara Global," Jurnal Kesehatan Masyarakat Andalas Program Studi Kesehatan Masyarakat Fakultas Kesehatan Masyarakat Universitas Andalas, (2), 2015: 80-87.

4 Mubadalah Adalah Pemikirah Faqiuddin Abdul Qodir. IAIN Ponorogo pernah mengundang beliau dan melakukan sharing bersama dosen dan Kepala KUA di Kabupaten Ponorogo. Baca Rohmah Maulidia, "The Implementation Of Presidential Decree On Gender Mainstreaming: Insights From IAIN Ponorogo," Justicia Islamica: Jurnal Kajian Hukum Dan Sosial, 149 Vol.18, No. 1, June 2021, 149-167.
} 


\section{PEMBAHASAN}

\section{Biografi Syekh Nawawi bin Umar Al-Bantani}

1. Kelahiran dan Silsilah Keturunan

Pada ujung abad ke-19 Masehi, di negeri Makkah terkenal seorang ulama besar. Ia adalah salah seorang guru besar pengikut Madzhab Syafi'i. Ia memiliki murid beratusratus yang berasal dari Banten, Cirebon, dan daerah Sunda, bahkan ada juga yang berasal dari Jawa, Melayu, Minangkabau, Sulawesi, Aceh, Ternate, dan daerah lain. Ia telah menulis beberapa kitab, terutama dalam bahasa Arab, hal ini yang kemudian membuat Ia terkenal sampai ke Mesir, Syiria, Turki, dan Hindustan. Hampir seluruh dunia Islam mengenal namanya. Ulama besar tersebut Bernama Syaikh Nawawi alBantani al-Jawi. ${ }^{5}$

Syekh Nawawi Al-Bantani dikenal sebagai seorang ulama yang mumpuni. Dia adalah orang Jawa dari Banten yang kemudian mengangkat harkat dan martabat orangorang dan Indonesia dalam bidang keilmuan di tanah suci. Bahkan oleh para ulama di Arab, Syekh Nawawi diberi gelar "Sayyid Ulama Hijaz", yang artinya Penghulu Ulama Hijaz (Makkah dan Madinah). ${ }^{6}$

Syekh Nawawi Al-Bantani lahir di desa Tanara, Serang, Banten pada tahun 1230 H/1815 M. Nama lengkapnya Abu Abd al-Mu'ti Muhammad Nawawi ibn Umar at-Tanari al-Jawi al-Bantani. Ia lahir dari keluarga yang saleh dan memiliki tradisi religius sebagai keturunan dari keluarga raja-raja dan bangsawan kesultanan Banten. Ayahnya, KH. Umar bin Arabi adalah ulama dan penghulu desa Tanara juga pemimpin sebuah masjid di desa yang menjadi cikal bakal berdirinya pesantren milik keluarganya. Ibunya bernama Nyai Zubaidah, seorang wanita salehah dan taat beragama. $^{7}$

Syekh Nawawi adalah empat bersaudara laki-laki, yaitu Abdullah, Tamim dan dua saudara perempuan lainnya, yaitu Syakila dan Syahriya. Ayahnya adalah seorang ulama' yang memimpin masjid dan pendidikan Islam di Tanara. Berdasarkan silsilah keturunan, Syekh Nawawi merupakan kesultanan yang ke-12 dari Maulana Syarif Hidayatullah (Sunan Gunung Jati), yaitu keturunan dari putra Maulana Hasanuddin (Sultan Banten I) yang bernama Suryaararas (Tajul Arsy). ${ }^{8}$

Saat Syekh Nawawi lahir, kesultanan Banten sedang berada diambang keruntuhan. Raja yang memerintah saat itu Sultan Rafi'uddin (1813 M), diturunkan secara paksa oleh Gubernur Rafles untuk diserahkan kepada Sultan Mahmud Syafi'uddin, dengan alasan tidak dapat mengamankan negara. Pada tahun peralihan kesultanan tersebut (1816 M), di Banten sudah terdapa Bupati yang diangkat oleh Pemerintah Belanda. Bupati pertama bernama Aria Adisenta. Namun, setahun Samsul Munir Amin, Karomah Para Kyai (Yogyakarta: Pustaka Pesantren, 2008), 11.

6 Ibid., 231. 2017), 189.

Suwarjin, "Biografi Intelektual Syekh Nawawi Al-Bantani", Tsaqofah Tarikh, 2 (Juli-Desember

Samsul Munir Amin, Sayyid Ulama Hijaz Biografi Syaikh Nawawi Al-Bantani, (Yogyakarta: Pustaka Pesantrean, 2009), 14. 


\section{2| Argumentasi Syekh Nawawi bin Umar Al-Bantani}

kemudian diadakan pula jabatan Residen yang dijabat oleh orang Belanda sendiri. Akibatnya, pada tahun 1832 M, Istan Banten dipindahkan ke Serang oleh Pemerintah Belanda. Inilah akhir Kesultanan Banten yang didirkan oleh Sunan Gunung Jati pada tahun 1527 M. Kondisi sosil politik semacam inilah yang melingkupi kehidupan Syekh Nawawi kecil. ${ }^{9}$

Syekh Nawawi meninggal dunia dengan usia 84 tahun di Mekkah pada tanggal 25 Syawwal 1340 H/ 1897 M. Makannya terletak di pemakaman Ma'la, diseberang kuburan Khadijah, dekat dengan kuburan Asma, putri Khalifah Abu Bakar, dan sahabat nabi, Abdullah bin Zubair. ${ }^{10}$

\section{Pendidikan dan Kehidupan Sosial}

Pada usia lima tahun beliau belajar langsung dibawah asuhan ayahandanya, "Umar bin Araby. Seorang ulama yang pertama membangun pondok pesantren di daerahnya. Dari ayahnya lah Syekh Nawawi mendapatkan ilmu pengetahuan khususnya ilmu agama sepertti Bahasa Arab, tauhid, fiqih, dan tafsir. Setelah itu, barulah Syekh Nawawi dan kedua adiknya, Ahmad dan Tamim belajar kepada ulama-ulama lain seperti Kyai Sahal di Bantam dan Kyai Yusuf seorang ulama terkenal di Purwakarta. ${ }^{11}$

Ketika menjelang usia delapan tahun Syekh Nawawi berangkat ke Jawa Timur untuk menimba ilmu bersama saudaranya, yaitu selama tiga tahun. Disana Ia belajar di pusat keilmuan, tanah Jawa menjadikan Syekh Nawawi kecil sebagai seseorang yang memiliki ilmu yang memadai untuk mengajar di Banten. Namun, syekh Nawawi pribadi yang tidak mudah puas dengan ilmu. Oleh karena itu, pada tahun 1828, di usianya 15 tahun, Syekh Nawawi berangkat ke Makkah untuk belajar ilmu agama yang tinggi sekaligus menunaikan ibadah haji. ${ }^{12}$

Selama tiga tahun di Makkah, Syekh Nawawi sibuk belajar dari tokoh-tokoh ulama Makkah dan Madinah, mengisi akal budinya dengan segala corak keilmuan yang bernafaskan keagamaan serta mempelajari pula sikap para ulama yang diguruinya. Setelah tiga tahun berlalu, ia berniat pulang ke Banten untuk mengamalkan segenap ilmunya. Oleh para gurunya, pemuda Syekh Nawawi diijinkan dan dibekali dengan doa restu. ${ }^{13}$

Setelah kembali dari Makkah, Syekh Nawawi melanjutkan kegiatan mengajar di Tanara. Melalui ilmu keagamaannya yang luas, hal tersebut menarik banyak murid untuk belajar kepada beliau. Namun di sisi lain hal ini menjadi ancaman bagi kekuasan Belanda, karena popularitas dan jumlah murid yang terus meningkat. Oleh karena itu akhirnya pemerintah Belanda mengawasi aktivitas mengajar beliau. Karena merasa diawasi, Syekh Nawawi kurang merasa nyaman. Akhirnya beliau memutuskan untuk

\footnotetext{
Kholilurrohman, Menelusuri Distorsi Dalam Ilmu Kalam (Tangerang: Nurul Hikmah Press, 2018), 798.

10 Zamakhsyari Dhofier, Tradisi Pesantren (Jakarta: Lp3es, 1982), 87.

11 Yasin, Melacak Pemikiran Syaikh Nawawi Al-Bantani (Semarang: Rasail Media Group, Cetakan 1, 2007), 61.

12 Samsul Munir Amin, Sayyid Ulama Hijaz Biografi Syaikh Nawawi Al-Bantani, 51.

13 Ibid., 36.
} 


\section{Argumentasi Syekh Nawawi bin Umar Al-Bantani | 63}

kembali ke Makkah, yaitu sekitar tahun 1855 dan menetap disana, dan tinggal di perkampungan Syi'ib Ali. Dan setelah itu, Syekh Nawawi tidak pernah kembali lagi ke tanah airnya. ${ }^{14}$

Menurut Chaidar, selama menetap di Makkah Syekh Nawawi melanjutkan kegiatan mengajar di Masjid al-Haram. Tidak jauh berbeda dengan yang terjadi di Indonesai, ada sekitar 200 murid menghadiri kuliahnya. Diantara para murid Syekh Nawawi yang terkenal sebagai ulama Nusantara, antara lain adalah: KH. Khalil Bangkalan Madura, Hasyim Asy'ari Jombang, KH. Raden Asnawi Kudus, KH. Tubagus Muhammad Asnawi Caringin, dan banyak lagi ulama yang lain. ${ }^{15}$

Terkait dengan kehidupan berkeluarga, diperoleh keterangan bahwa Syaikh Nawawi selama hidupnya menikah dengan dua wanita, yaitu Nasimah dan Hamdanah. Dari kedua istrinya, Syaikh Nawawi mempunyai lima orang anak, yaitu: Mariam, Nafisah, Ruqayah, Zuhra, dan Abdul Mu'thi. Dari kelima anaknya, hanya satu orang yang laki-laki, yakni Abdul Mu'thi, anak terakhir. Meskipun demikian, Abdul Mu'thi meninggal sejak masih kecil. Itulah sebabnya, Syaikh Nawawi juga mendapatkan julukan sebagai Abu Abdul Mu'thi, yang berarti Bapaknya Abdul Mu'thi. Nama Abu Abdul Mu'thi beliau cantumkan dalam salah satu karyanya yaitu dalam kitab Nihāyah az-Zain. ${ }^{16}$

\section{Karya}

Berdasarkan literatur dan berbagai sumber yang ada, karya tulis Syekh Nawawi bin Umar al-Bantani telah diterbitkan dan tersebar luas di berbagai daerah, baik di Indonesia maupun di berbagai wilayah dunia Islam lainnya. Karya-karya Syekh Nawawi tersebut antara lain: ${ }^{17}$

a. Ilmu Bidang Tauhid.

1) Tijān Ad-Durāri 'alā risālati al-'àlim al-'alāmah Shaikh Ibrāhim al-Bājuri fi Tauhid.

2) Al-Thimār al-Yāni'at fì Riyadh al-Badi'at.

3) Dhariatul Yaqìn 'alà Ummī al-Barahin.

4) Fathu al-Majid.

5) Qāmi'ut Tughyān, 'alā Manžùmat Syu'ab al-İman.

6) Qathru al-Ghaith sharaḥ 'alā Masāil Abī Laith.

7) An-Nahjah al-Jayyidah.

8) Nür Az-Zalām, sharaḥ 'alā Manżūmah 'Aqīdatul 'Awām.

9) Al-Futūhāàt al-Madaniyah, sharah 'alā Shu'ab al-İmāniyyah.

10) Mirqātu șu'üd at-Tașdīq, sharah 'alā Sulam at-Taufiq.

11) Al-'Aqduth Thamin, sharah fì bayāni Masāil ad-Dìn.

12) Hidāyatus As-Șibyan 'alā Fathu Ar-Raḥman.

\footnotetext{
${ }_{14}$ Ahmad Syatibi, Jejak Syekh Nawawi Al-Bantani (Banten: Harian Fajar Banten, 2004$), 7$.

15 Samsul Munir Amin, Sayyid Ulama Hijaz Biografi Syaikh Nawawi Al-Bantani, 51.

16 Ibid.,79-80.

17 Ibid., 59-65.
} 
64 Argumentasi Syekh Nawawi bin Umar Al-Bantani

13) Bahjatu al-Wasail.

b. Ilmu Bidang Tarikh atau Sejarah

1) Al-Ibrìz al-Dani fi Maulidì Sayyidinā Muhammad Sayyidi al-Adnani.

2) Bughyatu al-Anam.

3) Targhìbu al-Mustāqīn.

4) Madìriju aș-Ṣu'ud (Kitab Maulid Al-Barzanji).

5) Sharah al-Burdah.

6) Fathu aș-Ṣamad, sharah 'alā Maulid An-Nabawī.

c. Ilmu Bidang Fiqih

1) Nihāyah az-Zain, sharah 'alā Qurratu al-'Ain bi Muhimmāti ad-Dìn.

2) Al-Tauṣiyah, sharah 'alā Fathu al-Qarīb al-Mujīb.

3) Sullam al-munajāt, sharah 'alā Safinat aș-Ṣalāt.

4) Șarhu 'Uqūdullujain fi Bayāni Ḧuqūqu Zaujain.

5) Sulūkal-Jādah.

6) Qūtal-Habib al-Gharìb.

7) Kāshifat as-Sajā, sharaḥ 'alā Safinat an-Najā.

8) Fathu al-Mujib al-Qarib.

c. Ilmu Bidang Tasawwuf

1) Salālimu Al-Fudalāā, sharah 'alā Bidāyat al-Hidāyah.

2) Miṣbāh az-Zulām 'alā al-Hikām.

3) Nașāih al-'Ibād 'alā Al-Munbihāt 'alā al-Isti'dād Liyaum al-mī'ād.

d. Ilmu Bidang Hadits

Tanqih al-Qaul al-Hathith, fi Lubäb al-Hadith. Kitab ini membahas 40 hadits tentang keutamaan-keutamaan. Kitab ini berisi ulasan dari karya Imam Jalaluddin AlSyuyuthi.

e. Bidang Tafsir

Tafsìr Al-Munìr (Marāh al-Labìd Likashfi Ma'na Al-Qur'än al-Majìd). Kitab ini berisi tafsir Al-Qur'an 30 juz. Kitab ini terdiri dari 2 jilid. Tafsīr ini merupakan karya terbesar Syekh Nawawi. Syekh Nawawi juga mendapat predikat Sayyiddu Ulama al-Hijaz melalui Tafsir ini.

f. Bidang Ilmu Alat

1) Fathu al-Ghafir al-Hatiyyah, sharah 'alā nazam al-Jurūmiyyah.

2) Al-Fuṣūṣu al-Yāqūtiyyah, sharaḥ 'alā Raudatul Bahiyyah fi Abwābi al-Tașrīinyyah.

3) Lubāb al-Bayān.

4) Kashfal-Marutiyyah 'an Sattarī al-Jurümiyyah.

Karya-karya yang disebutkan di atas adalah karya Syekh Nawawi yang sudah di cetak dan diterbitkan oleh berbagai penerbit. Kitab-kitab tersebut tersebar di hampir seluruh wilayah dunia Islam. Di Indonesia, karya-karya Syekh Nawawi bisa didapati di berbagai toko kitab di berbagai kota. Di samping itu, masih banyak karya Syekh 


\section{Argumentasi Syekh Nawawi bin Umar Al-Bantani | 65}

Nawawi yang belum sempat terbit dan masih berupa manuskrip yang tersimpan di Mesir maupun di Arab. ${ }^{18}$

\section{Substansi Kitab 'Uqū dullujain}

Sharah 'Uqüdullujain merupakan karya fiqh Syekh Nawawi, dan karya ini merupakan karya yang paling populer di kalangan santri. Kitab ini diantaranya berisi konsepkonsep dasar kehidupan suami-istri. Dalam kitab tersebutSyekh Nawawi menyebutkan bahwa sebaik-baik suami adalah suami yang paling baik di mata keluarganya, dan sebaik-baik istri adalah yang mampu menangani urusan keluarganya dengan baik. Adapun topik inti kitab Uqüdullujain ialah hak dan kewajiban suami-istri. ${ }^{19}$

Menurut KH. Husein Muhammad, Kitab 'Uqūdullujain mungkin dianggap sebagai satu-satunya kitab yang (masih) paling merepresentasikan kehidupan suamiistri. Oleh karenanya kitab ini banyak dijadikan sebagai pedoman oleh berbagai kalangan yang meyakininya, dan tentu sangat mempengaruhi sikap serta pandangan bagi pembacanya. ${ }^{20} \mathrm{Kitab}$ ini ditulis karena munculnya permintaan yang kuat dari masyarakat pada saat itu, tentang penjelasan yang menguraikan interaksi suamiistri, dan harapannya melalui penjelasan yang disampaikan oleh Sykh Nawawi dapat memberikan manfaat bagi orang yang menginginkannya. ${ }^{21}$

Merujuk pada perkataan Ibu Hj. Sinta Nuriyah (istri Gus Dur) dalam kajian FK3 (Forum Kajian Kitab Kuning) bahwasannya teks-teks ḥadīth dalam kitab ‘Uqūdullujain banyak yang tidak șahi hh, bahkan banyak juga yang $d a^{\prime} i f^{22}$

1. Materi Kitab 'Uqūdullujain

Ada empat pasal (bab) yang dituangkan dalam kitab ‘Uqūdullujain tersebut, berikut penjelasannya:

a. Kewajiban Suami terhadap Istri

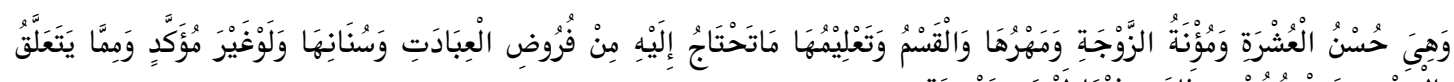

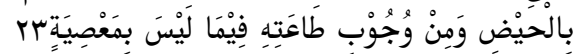

Bab ini memuat tentang keharmonisan, nafkah, mahar (maskawin), jadwal berkunjung, mendidik istri tentang keagamaan, seperti fardlu dan sunnahnya ibadah, haiḍ, serta wajibnya taat kepada suami selama bukan merupakan maksiat.

b. Kewajiban Istri terhadap Suami.

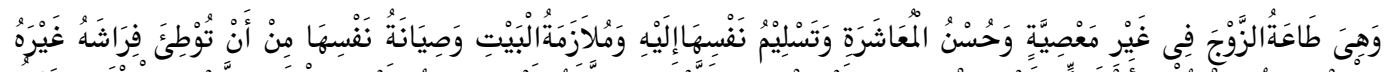

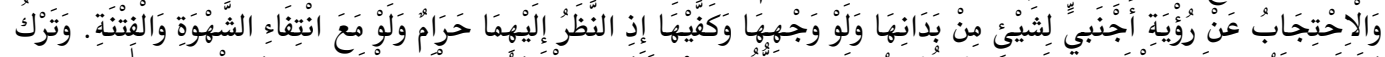

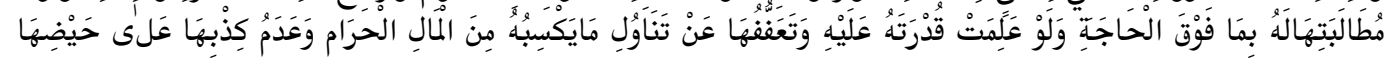

\footnotetext{
$18 \quad$ Ibid., 66.

19 Ibid., 57.

20 Muhammad Husein, Fiqih Perempuan, 174.

21 Afif Bustomi Dan Mansyuri Ikhwan, Etika Berumah Tangga, (Jakarta: Pustaka Setia, 2000$), 3$.

22 Forum Kajian Kitab Kuning (Fk3), Wajah Baru Relasi Suami Istri Telaah Kitab 'Uqūdullujain, (Yogyakarta: Lkis Yogyakarta, 2001), Xii

${ }_{23}$ Sharaḥ 'Uqūdullujain Fì Bayāni Ḥ̣qūq Az-Zaujayn, (Surabaya: Maktabah Imaratullah, (T.Th)), 3.
} 
Pada bab ini dikupas tentang taat kepada suami pada selain maksiat, keharmonisan, menyerahkan diri sepenuhnya kepada suami, menjaga rumah, menjaga kehormatan, menghindar dari padangan laki-laki lain, menghindari fitnah, tidak menuntut suami melebihi kemampuan, menolak pemberian suami yang berasal dari pekerjaan yang haram, tidak berbohong tentang keadaan haid kepada suami.

c. Shalat dirumah bagi perempuan lebih utama daripada sholatnya perempuan di masjid dengan nabi SAW.

Pada bab ini membahas keutamaan wanita salat di rumah daripada salat bersama sebagaimana sabda Nabi SAW:

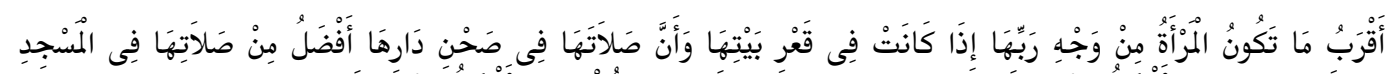

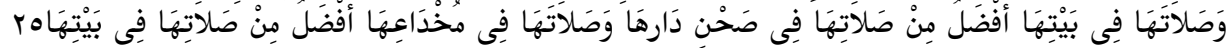

Artinya: "Wanita yang paling dekat dengan Alah adalah wanita yang berada di dalam rumahnya, shalatnya seorang wanita di halaman rumahnya lebih utama daripada shalat di masjid, dan shalatnya wanita di dalam rumah lebih utama dari shalat di halaman rumahnya, sedangkan ssalatnya di dalam kamar lebih utama dibanding shalat di dalam rumah yang tidak berada di kamar."

Maksudnya, salat seorang wanita akan lebih baik jika dilakukan di ruangan yang lebih tertutup untuk menghindari timbulnya fitnah.

d. Larangan melihat lawan jenis

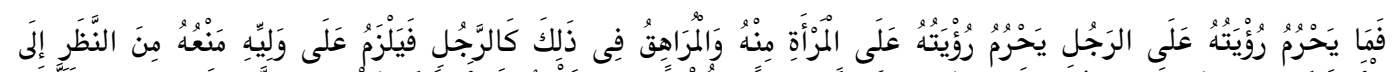

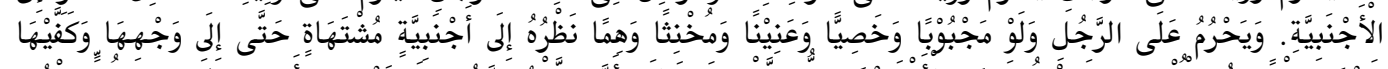

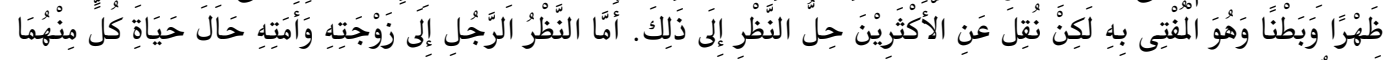
فَجَائزُنَ

Bab ini membahas larangan bagi laki-laki memandang wanita lain pada hal-hal yang haram untuk dipandang, dan sebaliknya. Seorang laki-laki diharamkan memandang wanita lain yang disukainya, termasuk wajah dan telapak tangannya (atas bawah), walaupun laki-laki tersebut terpotong kemaluannya, impoten, banci, sudah tua renta. Inilah hukum yang difatwakan. Akan tetapi menurut mayoritas ulama memandang wajah dan telapak tangan wanita adalah halal.

Seorang laki-laki diperbolehkan memandang wajah dan kedua telapak tangan wanita merdeka yang akan dinikahinya. Memandang wanita juga diperbolehkan dalam hal persaksian dan transaksi, dan untuk tujuan pengajaran hal-hal yang wajib diketahui oleh wanita.

Penutup dari kitab 'Uqüdullujain berisi tentang beberapa tingkah laku wanita pada zaman ini (Syekh Nawawi) yang sering dijumpai seperti para perempuan bertabarruj (menampakkan perhiasan dan kecantikannya dihadapan kaum

24 Ibid.

25 Ibid.

26 Ibid. 


\section{Argumentasi Syekh Nawawi bin Umar Al-Bantani | 67}

laki-laki), berani berjalan diantara kaum laki-laki. Sengaja berjalan dengan genit dihadapan kaum laki-laki. Oleh karena itu, Syekh Nawawi berpesan untuk:

1) Melarang istri dan para anak perempuannya berdandan Ketika hendak keluar rumah.

2) Menjaga keluarga secara optimal dan agar tidak lengah sedikitpun kecuali dalam kadar yang wajar. ${ }^{27}$

2. Kedudukan Perempuan dalam Kitab 'Uqūdullujain

a. Perempuan berada satu tingkat di bawah laki-laki.

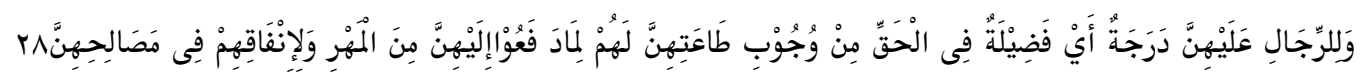

Maksud dari makna "suami mempunyai satu tingkatan kelebihan daripada istrinya" memposisikan bahwa suami wajib ditaati oleh istrinya, hal ini dikarenakan suami telah memberi maskawin (mahar) dan nafkah untuk istrinya.

Diriwayatkan dari Nabi SAW, beliau bersabda saat menunaikan haji wada':

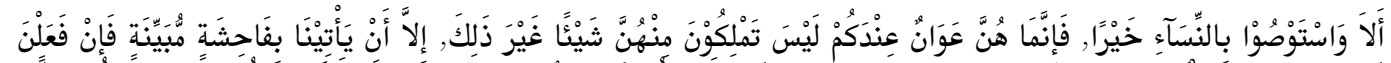

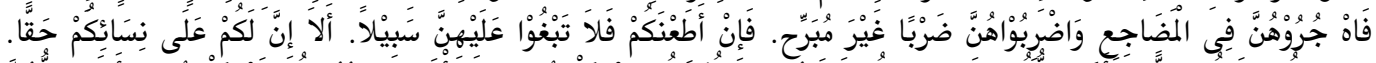

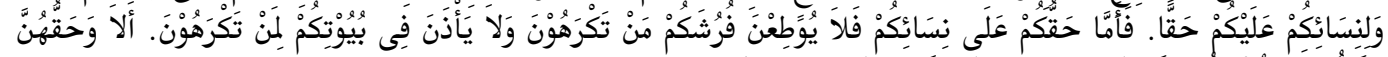

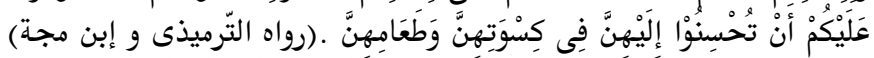
Artinya: "Ingatlah, berikan wasiat kebaikan kepada para wanita, karena mereka (para wanita) laksana tawanan bagi kalian. Sesungguhnya kalian tidak memiliki hak apapun dari mereka kecuali kebaikan, kecuali jika mereka (wanita) melakukan perbuatan buruk yang jelas (seperti menentang/purik; jawa). Kalau perempuan itu melakukan perbuatan tercela, maka pisahranjanglah dan pukullah dengan pukulan yang tidak menyakitkan. Kalau wanita itu mentaati kalian, maka janganlah kalian mencari-cari alasan lain untuk mengusiknya. Ingatlah, sesungguhnya kalian memiliki hak atas istri kalian, dan istri kalian memiliki hak atas kalian. Dan diantara hak kalian atas istri kalian adalah melarang istri menggelar tikar kalian untuk orang yang tidak kalian sukai dan istri kalian tidak boleh mengizinkan masuknya orang yang tidak kalian sukai. Ingatlah, bahwa hak istri kalian atas kalian adalah mendaparkan pakaian dan nafkah yang layak." (HR. Tirmidzi dan Ibn Majah)

Syekh Nawawi 'Uqūdullujain mengungkapkan alasan suami boleh memukul istri, yaitu jika istri membantah perintah suami soal berhias dan urusan kasur, jika istri keluar rumah tanpa izin, jika istri memukul anak, jika istri mem-bully orang lain, jika istri merusak baju suami, jika istri menjambak jenggot suami, jika istri mengucapkan kata-kata tidak pantas seperti "bodoh" sekalipun itu bentuk perlawanan atas perlakuan suami yang tidak baik, menampakkan wajahnya kepada laki-laki yang bukan mahramnya, membagi harta suami di

27 Syekh Muhammad Bin Umar An-Nawawi, Keharmonisan Rumah Tangga Terjemahan Syarah`Uqüdullujain, Terj. Ali Maghfur Syadzili Iskandar (Surabaya: Al-Miftah, 2011), 107-108.

28 Sharaḥ 'Uqūdullujain Fì Bayāni Ḥuqūq Az-Zaujayn, 3 
68| Argumentasi Syekh Nawawi bin Umar Al-Bantani

luar batas kewajaran, serta menolak menjalin hubungan kekeluargaan dengan keluarga suami. ${ }^{29}$

b. Perempuan seperti layaknya seorang hamba sahaya.

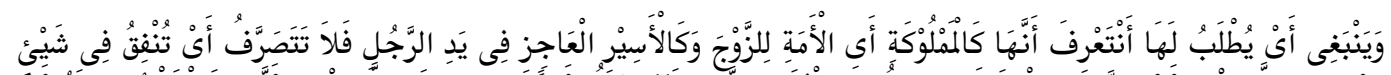

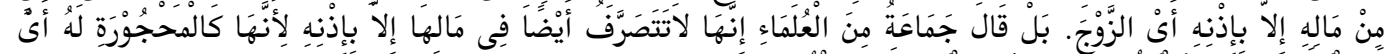

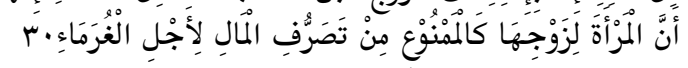

Bahwasannyaistritidaklebihdariseoranghambasayaha(budak) bagisuaminya.

Dan bagaikan tawakan yang tidak berdaya di hadapan suaminya. Maka dari itu tidak diperbolehkan menggunakan harta suami kecuali memperoleh izin dari suami itu sendiri. Bahkan pendapat ulama juga menyatakan bahwa istri tidak diperbolehkan menggunakan hartanya sekalipun harta itu mutlak milik istri itu sendiri, kecuali telah memperoleh izin suami. Sebab kedudukan istri layaknya orang yang mengandung banyak hutang, yang mana harus dibatasi penggunaan harta tersebut.

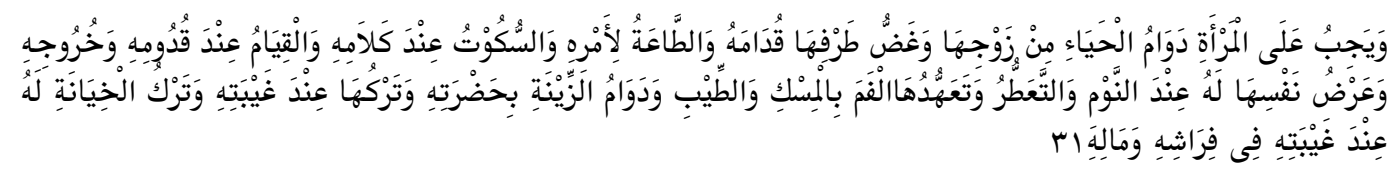

Wajib bagi seorang istri untuk memiliki sikap pemalu kepada suaminya sepanjang waktu dan tidak membantah perkataan suami, menundukkan pandangannya ketika dihadapan suami, mentaati perintah-perintahnya, menyambutkedatangan suami dan mengantarkannya ketika hendak bepergian, wajib menyerahkan dirinya secara penuh kepada suami ketiak menuju tempat tidur, selalu beraroma wangi, memperhatikan kebersihan mulutnya baik dengan menggunakan misik atau wewangian lain, menggunakan pakaian yang bersih, selalu bersolek di hadapan suami dan tidak berhias jika suami sedang bepergian.

c. Tidak boleh menolak ajakan berhubungan badan.

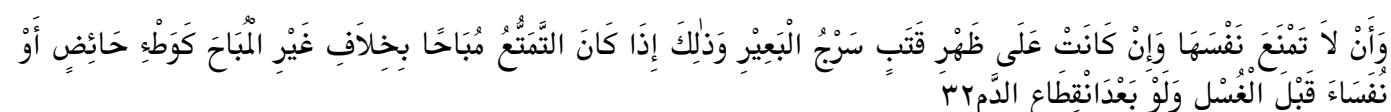

Istri tidak boleh menolak suami jika diajak berhubungan intim walaupun bertempat di punggung unta. Hal itu harus dilakukan selama boleh meakukan hubungan intim. Berbeda ketika diharamkan berhubungan seperti dalam keadaan haidl, nifas, sebelum mandi setelah darahnya tuntas.

Rasulullah SAW, bersabda:

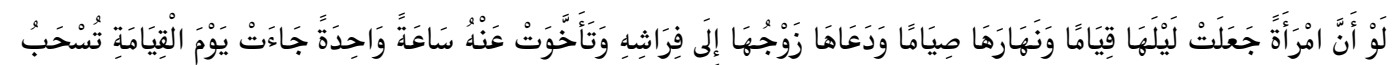

\footnotetext{
29 Syekh Muhammad Bin Umar An-Nawawi, Keharmonisan Rumah Tangga Terjemahan Syarah 'Uqüdullujain, 27-28.

30 Sharah 'Uqūdullujain Fì Bayāni Ḥqū̄q Az-Zaujayn,8

31 Ibid.

32 Ibid.
} 


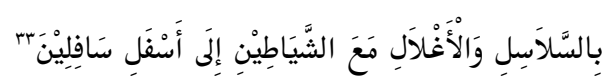

Seandainya seorang istri menjadikan seluruh waktu malamnya untuk beribadah dan siangnya selalu berpuasa, sementara ketika suaminya mengajak dia tidur bersama (bersetubuh) dan ia terlambat sebentar saja memenuhi panggilan (ajakan) suaminya, maka kelak di hari kiamat ia datang dalam keadaan terantai dan terbelenggu, serta ia dikumpulan bersama syetan di neraka yang paling bawah.

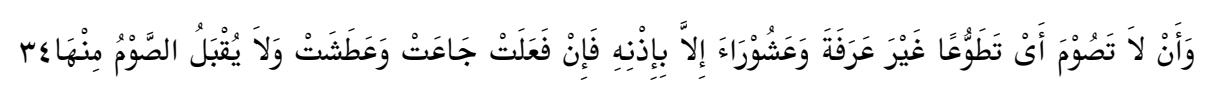

Seorang istri tidak diperbolehkan berpuasa (sunnah) selain puasa Arafah dan Asyura selama tidak mendapat izin dari suaminya, apabila tetap berpuasa dengan tanpa mendapat izinnya maka puasanya hanya menghasilkan lapar dan dahaga serta tidak diterima.

d. Perempuan tidak boleh meminta cerai kepada suami.

Nabi Muhammad SAW, Bersabda:

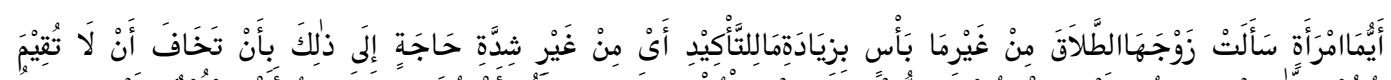

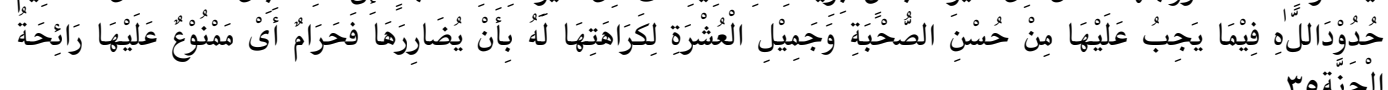

Wanita manapun yang menuntut cerai kepada suaminya tanpa ada alasan atau perkara yang memperbolehkannya sama sekali yakni dengan secara jelas tanpa mengagungkan ketetapan Allah maka diharamkan atau di cegah dia untuk mencium baunya surga.

Abu Bakar Ash-Shiddiq RA. mendengar Rasulullah SAW. bersabda:

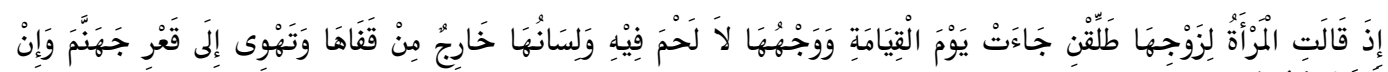

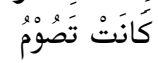

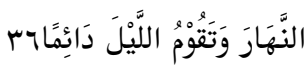

Apabila seorang wanita berkata kepada suaminya: "Ceraikanlah aku," maka kelak di hari kiamat ia memiliki wajah tanpa terbalut daging, sementara lidahnya menjulur keluar dari langit-langit mulut dan ia turun menuju tengahtengah jurang neraka, kendati ia selalu berpuasa pada siang hari dan beribadah di waktu malam.

e. Perempuan harus mendapat izin dari suami apabila ingin bepergian.

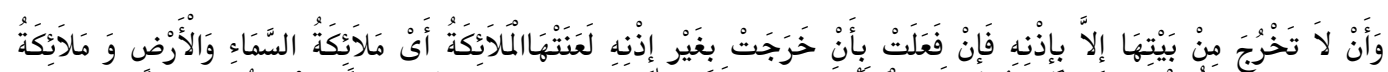

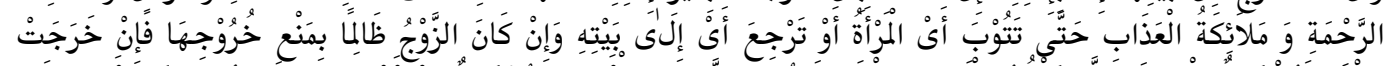

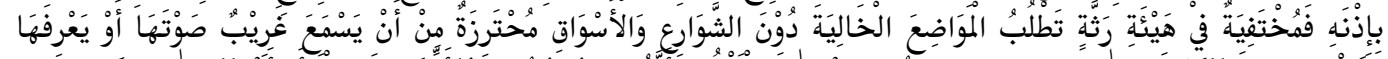

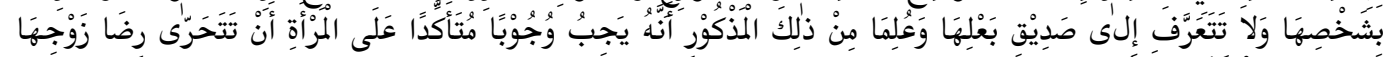
Ibid., 9 .
Ibid.
Ibid., 10.
Ibid., 11 .
Ibid., 9. 


\section{0 | Argumentasi Syekh Nawawi bin Umar Al-Bantani}

Istri hendaknya tidak bepergian dari rumah kecuali mendapat izin dari suaminya. Jika keluar tanpa izin suaminya, maka ia mendapat kutukan dari para malaikat, yaitu para malaikat langit dan bumi, serta malaikat pembawa rahmat dan pembawa azab hingga ia meminta maaf atau hingga ia kembali ke rumahnya. Kalaupun keluar rumah dengan izin suami, hendaknya dengan menyamar dan mengenakan pakaian yang tidak baik. Carilah tempat yang sepi, bukan jalan umum atau pasar, juga menjaga diri agar orang lain tidak sampai mendengar suara atau melihat postur tubuhnya. Istri tidak boleh memperlihatkan dirinya kepada teman suaminya. Dari keterangan tersebut dapat dimengerti bahwa istri sedapat mungkin benar-benar wajib memelihara keridhaan suami dan menjauhi kemunkarannya sedapat mungkin.

Sahabat Utsman Bin Affan RA. menyatakan pernah mendengar Rasulullah SAW. bersabda:

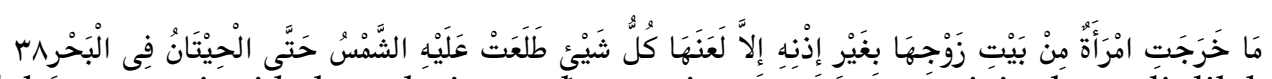

Tidaklah seorang istri keluar dari rumah suaminya yang tanpa izin, kecuali dilaknati oleh segala sesuatu yang terkena sinar matahari, bahkan ikan-ikan yang ada di laut.

3. Metode Istidlāl Syekh Nawawi bin Umar Al-Bantani dalam Kitab 'Uqūdullujain Tentang Konsep Kesetaraan Perempuan Dalam Keluarga

Pemikiran Syekh Nawawi lekat dengan tradisionalisme dan sufisme. Hal ini terlihat misalnya pada upaya-upaya mempertahankan tradisi yang mapan. ${ }^{39}$ Sementara sufisme sering ditampilkan dalam fenomena gemar beribadah dan rajin melakukan ritus-ritus yang mendalam, intens, dan asketis. ${ }^{40}$

Karya Syekh Nawawi lebih banyak dalam bentuk sharah, namun kadang-kadang melepaskan dari teks asli dengan menampilkan pendapat sendiri yang menguatkan teks (pendapat) atau berlainan. Dalam menentukan hukum (kesimpulan hukum), Syekh Nawawi lebih suka mengumpulkan pendapat-pendapat ulama, lalu meraciknya dengan penambahan bumbu dari padanya, tersimpullah sebuah hukum. Jika landasan hukum itu bersumber dari Al-Qur'an, beliau lebih suka membahasnya dengan lewat I'rāb kalimat. Jika bertemu dengan sumber Al-Hadìts, beliau seringkali tidak menyatakan sanadnya dahulu, walaupun hanya bersifat informatif (bukan tarjīh). ${ }^{41}$

Seperti sabda Nabi saat menunaikan haji wada':

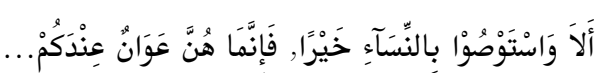

Artinya: “Ingatlah, berikan wasiat kebaikan kepada para wanita, karena mereka (para wanita) laksana tawanan bagi kalian."

38 Ibid., 10 .

39 Ahmad Fatah "Mendambakan Paradigma Kesetaraan Dalam Pernikahan (Telaah Kritis Terhadap Kitab 'Uqūdullujain),” Jurnal Penelitian 2 (Agustus 2014), 351.

40 Husein Muhammad, Figh Perempuan, 174

41 Ahmad Sanusi "Pemikiran Nawawi Al-Bantani Tentang Munakahat Dan Relasi Gender," Alqalam 32 (Januari-Juni 2015), 150. 


\section{Argumentasi Syekh Nawawi bin Umar Al-Bantani | 71}

Huruf ba pada kata بالنساء mengandung arti ta'diyayah. Kata خير dibaca nașab dan memiliki dua kedudukan. Pertama, sebagai maf'ul (objek) dari kata إستوا خيروا sehingga berarti lakukanlah hal yang terbaik bagi mereka. Kedua, kata خيرا berarti terimalah wasiatku ini dan lakukanlah hal yang terbaik. ${ }^{42}$ Dari penjelasan diatas dipahami bahwa pada awal Nabi berkhutbah, beliau menekankan untuk melaksanakan wasiatnya dengan kesungguhan.

Kata 'awānin pada ḥadit diatas adalah bentuk jamak dari 'Aniyah, yang diantara artinya adalah tawanan. Syekh Nawawi mengartikan kata 'awānin dengan tawanan atau tahanan, sehingga perempuan (istri) oleh Syekh Nawawi dianggap sebagai tawanan atau tahanan laki-laki (suami) ${ }^{43}$ Maksud dari "mereka (para wanita) laksana tawanan bagi kalian," yaitu istri adalah amanah yang harus dijaga, dan mereka memiliki keterbatasan hak yaitu harus selalu taat dan patuh kepada suami selama bukan dalam hal maksiat. ${ }^{44}$

Kitab 'Uqūdullujain ini ditulis berdasarkan perkataan-perkataan ulama yang terdapat dalam sembilan kitab: Al-Zawäjir karya Syaikh Ibn Hajar al-Haitami, Ihyā 'Ulūmu ad-Dīn karya Imam Al-Ghazali, Targhïb wa at-Tarhīb karangan al-Imam alHafizh Zakiyy ad-Din Abd Al-Adhim ibn Abd Qawwim al Mundziri as-Syafi'i, al-Jawāhir karya Abu Laits as-Samarqandi, al-Kabāir karya adz-Dzahabi, kitab Jāmi' aș-Ṣaghìr karya Jalal ad-Diin Abdurrahman al Suyuthi, Kitab Sharah Ghāyat alIkhtișār karya Abu Syuja', Kitab Tafsìr al- Khāzin yang ditulis oleh Alau ad-Diin Ali ibn Muhammad al-Baghdadi, dan Tafsìr Ash-Sharbini al-Hatīb. ${ }^{45}$

Dengan demikian rujukan yang dipakai dalam Kitab'Uqūdullujain adalah cerminan dari pemikiran Syekh Nawawi sekaligus merupakan karya yang banyak merujuk pada kitab-kitab yang telah ada sebelumnya, terutama yang dominan adalah rujukan terhadap karya Imam Al-Ghazali Ihyā ‘Ulümu ad-Dīn. Oleh karena sangat dominannya kutipan Syekh Nawawi terhadap Ihyā, dapat dikatakan bahwa kitab 'Uqüdullujain adalah ringkasan dari bab nikah Kitab Ihya. ${ }^{46}$

Syekh Nawawi, dalam kitab ini mengutip lebih dari 100 buah hadits dan hikayathikayat. Cerita ini dipaparkan untuk mendukung suatu hadits yang terkait, atau untuk menjelaskan maknanya. Dalam hal ini, beliau sering kali tidak memberikan catatan apa-apa tentang nilai keabsahannya, karena memang kitab ini berisi petunjuk-petunjuk praktis bagaimana seharusnya orang membina rumah tangganya dengan baik. ${ }^{47}$

${ }^{42}$ Forum Kajian Kitab Kuning (Fk3), Wajah Baru Relasi Suami Istri Telaah Kitab ‘Uqūdullujain, 13.

43 Ibid., 14.

44 Syekh Muhammad Bin Umar An-Nawawi, Keharmonisan Rumah Tangga Terjemahan Syarah 'Uqūdullujain, 15.

${ }_{45}$ Forum Kajian Kitab Kuning (Fk), Wajah Baru Relasi Suami Istri Telaah Kitab Uqūdullijain, Xv.

46 Ahmad Fatah "Mendambakan Paradigma Kesetaraan Dalam Pernikahan (Telaah Kritis Terhadap Kitab ‘Uqudullijain),' 351-353.

47 Husein Muhammad, Figh Perempuan, 175. 


\section{2 | Argumentasi Syekh Nawawi bin Umar Al-Bantani}

Selain itu, beberapa hadith dalam kitab ini khusunya yang menyebutkan tentang kesetaraan perempuan dalam keluarga ada hadith yang dinilai da'if maupun maudu'. Seperti hadith yang yang diriwayatkan Sayyidina Utsman bin Affan RA: "Tidaklah seorang istri keluar dari rumah suaminya yang tanpa izin, kecuali dilaknati oleh segala sesuatu yang terkena sinar matahari, bahkan ikan-ikan yang ada di laut." ${ }^{48}$ Menurut Forum Kajian Kitab Kuning (FK3) bahwasanya tidak ditemukan perawi hadits ini dan kitab-kitab $m u^{\prime}$ 'tabar juga tidak menyebutkannya. Dengan demikian hadith tersebut adalah maudu' ${ }^{49}$

Dalam kitab 'Uqüdullujain, kisah-kisah irrasional yang bernuansa eskatologis banyak dikemukakan oleh Syekh Nawawi untuk mendukung pespektifnya yang bias gender. Misalnya, kisah totalitas ketaatan istri pada suami dan kisah tentang perempuan yang kelak akan diseret-seret ke api neraka karena sering membuka pakaiannya (tabarruj). ${ }^{50}$

\section{B. Analisis Pemikiran Syekh Nawawi bin Umar Al-Bantani Dalam Kitab ‘Uqū dullijain}

Tentang Konsep Kesetaraan Perempuan dalam Keluarga Perspektif Fiqh Kesetaraan Dalam konsep dan prinsip gender, secara jelas disebutkan bahwa dalam mengaktualisasikan tindakan diri laki-laki dan perempuan mempunyai hak yang sama. Begitu pula dalam kehidupan rumah tangga, suami dan istri memiliki keseimbangan dan kesetaraan dalam tindakan dalam bertindak. ${ }^{51}$ Sebagaimana firman Allah SWT:

Artinya: "Dan bergaullah dengan mereka (wanita) secara patut." 52

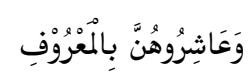

Pada saat Rasulullah SAW melaksanakan haji wada', beliau berkhutbah dan memberikan wasiat kepada hadirin untuk memperlakukan perempuan secara baik karena perempuan pada masa itu diibaratkan sebagai tawanan perang. Pernyataan ini pastilah akan membawa impikasi-implikasi lain yang merugikan bagi kaum perempuan. Hadits tersebut dapat dipahami dengan benar ketika kita melihatnya dalam konteks struktur sosial Arab dan semangat yang ingin disampaikan nabi. ${ }^{53}$

Syaikh Ibn Sidah, sebagaimana dikutip oleh Syaikh Ibn Manzhur dalam Lisan al-Arab, mengatakan:

Kaum perempuan disebut "tawanan" adalah karena mereka selalu ditindas dan tidak mendapat pembelaan dari masyarakatnya. Maka, hadist ini sebenarnya ingin memperingatkan kepada manusia tentang realitas perempuan pada ruang

48 Syekh Muhammad Bin Umar An-Nawawi, Keharmonisan Rumah Tangga Terjemahan Syarah 'Uqūdullujain, 57.

${ }^{49}$ Forum Kajian Kitab Kuning (Fk3), Wajah Baru Relasi Suami Istri Telaah Kitab ‘Uqūdullujain 77.

50 Ibid., 350.

51 Viani Rahmawati, Peran Perempuan Dalam Rumah Tangga Dalam Perspektif Keadilan Gender (Studi Kasus Di Dusun Watu Agung Desa Suruh Kecamatan Suruh Kabupaten Semarang), Skripsi (Salatiga: IAIN Salatiga: 2018), 107.

52 Al-Qur'an, 4: 19.

53 Husein Muhammad, Islam Agama Ramah Perempuan, 238. 


\section{Argumentasi Syekh Nawawi bin Umar Al-Bantani | 73}

dan waktu itu, dan menyerukan kepada mereka untuk menghentikan penindasanpenindasan itu sekaligus memerintahkan agar memperlakukan kaum perempuan secara khair (baik). ${ }^{54}$

Dari penjelasan Syaikh Ibn Sidah diatas, dapat diketahui bahwa yang disebut perempuan sebagai tawanan tidak hanya dalam rumah tangga saja, tetapi juga dalam tatanan sosial bangsa Arab. Karena pada masa itu, kondisi bangsa Arab masih dipengaruhi oleh budaya pada masa jahiliyah sebelum nabi lahir. Seperti telah diketahui, apabila ada anak perempuan lahir maka dianggap sebagai aib keluarga, oleh karena itu banyak bayi-bayi perempuan yang dikubur hidup-hidup oleh orang tuanya. Belum lagi jika perempuan telah dewasa maka dia harus memenuhi nafsu laki-laki tanpa harus dinikahi terlebih dahulu.

Pada bagiann sebelumnya telah diuraikan bahwa suami boleh memukul istrinya yang tidak berbakti kepadanya (Syaikh Muhammad Nawawi hlm 27-28). Begitu pula, istri tidak boleh keluar rumah tanpa izin suami, adapun bila ingin bepergian maka harus ada mahrom yang menemaninya. Dan ketika bepergian hendaknya melewati jalan yang sepi dan tidak banyak bertemu orang serta menggunakan pakaian yang sederhana yang tidak mengundang ketertarikan dan godaan lawan jenis. Dalam kitab ini juga disertakan hadits yang menyatakan bahwa istri akan mendapat laknat dari para malaikat apabila keluar rumah tanpa mendapat izin dari suami. ${ }^{55}$

Beberapa aturan dalam masalah domestik di atas hanya berlaku bagi perempuan saja, tidak ada aturan yang menyebutkan bahwa istri diperbolehkan memukul suami. Begitu pula ketika keluar rumah, suami tidak memerlukan izin dari istri terlebih dahulu, juga tidak perlu adanya mahram yang menemaninya. ${ }^{56}$

Pandangan yang mengatakan bahwa jika perempuan di luar rumah akan mendapat godaan laki-laki itu terlalu berlebihan. Semua bentuk kejahatan dan pelecehan dapat dilaporkan kepolisian dan diadukan ke pengadilan. ${ }^{57}$ Bahkan di beberapa negara, termasuk di antaranya negara muslim sudah diberlakukan sanksi yang berat terhadap pelaku pelecehan seksual meskipun kecil seperti hanya berupa sindiran. Oleh karena itu perempuan yang keluar dari rumah tidak perlu mendapat larangan yang berlebihan.

Larangan perempuan untuk pergi sholat ke masjid sebagaimana yang disebutkan pada bab sebelumnya adalah karena takut menimbulkan fitnah, maka pastilah perempuan juga akan dilarang ke pasar, jalan-jalan, dan ke tempat-tempat umum lainnya. Alasan lain adalah bahwa Rasulullah tidak pernah melarang perempuan pergi shalat bersama beliau di Masjid Nabawi sampai beliau wafat. Menyimak pendapat pengarang, larangan bagi perempuan untuk shalat diluar rumah

\footnotetext{
$54 \quad$ Ibid.

55 Syekh Muhammad Bin Umar An-Nawawi, Keharmonisan Rumah Tangga Terjemahan Syarah 'Uqūdullujain, 50.

56 Husein Muhammad, Islam Agama Ramah Perempuan, 125.

57 Forum Kajian Kitab Kuning (Fk3), Wajah Baru Relasi Suami Istri Telaah Kitab ‘Uqüdullujain, 174.
} 


\section{4 | Argumentasi Syekh Nawawi bin Umar Al-Bantani}

adalah untuk menghindari fitnah. Oleh karena itu, kalau kita yakin bahwa fitnh itu tidak akana ada, bahkan justru menambah syi'arnya agama Islam, maka shalat perempuan diluar rumah akan jauh lebih baik. ${ }^{58}$

Selain itu, kebutuhan perempuan untuk keluar rumah pada masa kini semakin beragam, mulai dari menuntut ilmu, mengantar anak ke sekolah, memenuhi kebutuhan rumah tangga, mengajar, berinteraksi sosial dengan orang lain. Untuk melakukan itu perempuan dituntut untuk berpenampilan baik dan sopan agar tidak dilecehkan atau direndahkan orang lain. Oleh karena itu, perempuan tidak perlu bersembunyisembunyi untuk keluar rumah dengan catatan telah mendapat izin dari suami atau memang ada keperluan.

Mengapa istri harus mendapat izin suami ketika pergi? Istri merupakan tanggung jawab suami, bukan hanya atas keselamatan fisiknya saja, tetapi juga nama baiknya istri. Pada hakikatnya, suamipun juga sebaiknya memberi tahu istri kemana dia menuju. Itu juga akan memberikan ketenangan bagi istri.

Dalam kitab ‘Uqüdullujain juga disebutkan apabila istri menolak ajakan suami untuk berhubungan badan tetapi ia menolak kemudian suami marah kepadanya maka malaikat akan melaknatnya sampai datang waktu subuh (HR. Bukhori). Jika acuannya berdasarkan keadilan/kesetaraan, tentunya suami juga harus dilaknat malaikat, sebab suami tidak memenuhi kebutuhan istrinya. Bahkan, suami yang demikian itu dapat dikatakan meninggalkan perintah Allah untuk menggauli istrinya secara ma'ruf. ${ }^{59}$

$\mathrm{KH}$. Husein Muhammad dalam bukunya yang berjudul "Hak Reproduksi Perempuan Menurut Islam" menulis: ${ }^{60}$

...relasi seksual suami-istri adalah relasi kemitraan dan bukan kekuasaan. Dalam arti lain, hak perempuan haruslah dipandang sama dengan hak laki-lak. Seorang istri dapat menuntut kenikmatan seksual dari suaminya, seperti sebaliknya.

Salah satu ciri perempuan yang masuk surga menurut Syekh Nawawi sebagaimana dinukil dari hadits Nabi SAW, adalah perempuan yang banyak melahirkan (produktif). Pandangan ini tentu saja sangat tidak selaras dengan tujuan perkawinan, sebab kesehatan perempuan (kesehatan reproduksi) juga merupakan faktor terwujudnya ketentraman serta kebahagiaan ibu ${ }^{61}$ Bahkan beberapa riset menunjukan bahwa terlalu sering melahirkan jmerupakan salah satu penyebab langsung tingginya angka kematian ibu melahirkan (AKI). ${ }^{62}$

Kelahiran anak merupakan anugerah Allah SWT yang tiada terhingga bagi orang tua, sekaligus menuntut tugas dan tanggung jawab yang besar bagi keduanya. Mulai dari merawat, mendidik, memberi sandang pangan yang cukup, memberi rasa aman dan perlindungan dari berbagai ancaman, memberikan pendidikan dan pengasuhan yang benar, agar kelak seorang anak menjadi orang yang berkuatias,

${ }_{58}$ Forum Kajian Kitab Kuning (Fk3), Wajah Baru Relasi Suami Istri Telaah Kitab 'Uqüdullujain, 115.

59 Abdul Djamil, Bias Jender Dalam Pemahaman Islam, 167.

60 Husein Muhammad, Islam Agama Ramah Perempuan, 21.

61 Siti Musdah Mulia, Muslimah Sejati Menempuh Jalan Islami Meraih Ridha Ilahi, 164.

62 Rohmah Maulidia, Kontribusi Pesantren pada MDGs (Surabaya: Imtiyaz, 2015), 25-33. 


\section{Argumentasi Syekh Nawawi bin Umar Al-Bantani | 75}

berguna dan berbakti kepada kedua orang tua. Oleh karena itu, kelahiran anak tidak hanya sebagai penerus kehidupan semata.

Menurut M. Quraish Shihab, kualitas berkaitan dengan banyak hal, utamanya pendidikan dan kesehatan. Ini berkaitan erat dengan kondisi ekonomi. ${ }^{63}$ Pendidikan dari orang tua merupakan salah satu tolak ukur keberhasilan dalam mendidik anakanaknya. Yang mana hal itu merupakan kewajiban bagi orang tua. Jika tugas tersebut gagal, maka anakpun bisa menjadi seorang yang durhaka. Dengan demikian, orang tua pun juga akan menerima akibatnya. ${ }^{64}$ Dari berbagai pertimbangan tersebut, maka kesiapan untuk memiliki atau menambah keturunan sebaiknya harus dipertimbangkan dengan baik. Mereka yang telah menikah tetapi belum mampu merawat anak, atau mereka yang sudah memiliki anak tetapi merasa bahwa menambahnya dapat menyulitkan keluarganya, maka mereka boleh merencanakan kelahiran anak selanjutnya.

Hak perempuan untuk mengatur kehamilan juga harus mendapat perhatian para suami. Apalagi jika kehamilan dapat menyebabkan terganggunya kesehatan reproduksinya. ${ }^{65}$ Upaya kontrasepsi atau KB sehat dapat dilakukan oleh kedua belah pihak suami atau istri berdasarkan pertimbangan kesehatan maupun kesetaraan gender yang diputuskan bersama melalui musyawarah bersama antara suami istri.

Dari uraian diatas dapat diketahui bahwa argumen Syekh Nawawi dalam Kitab 'Uqūdullujain cenderung patriakhis dan lebih membatasi ruang gerak bagi perempuan. Apalagi kalau diingat bahwa beliau menulis kitab ini dengan menggunakan metode penukilan dari ulama-ulama sebelumnya. Tidak menutup kemungkinan jika yang digambarkan dalam kitab tersebut adalah kondisi perempuan pada masa ulama sebelum beliau, bukan semata-mata karena kebenciannya terhadap kaum perempuan.

\section{Analisis Kritis Dasar Pemikiran Syekh Nawawi bin Umar Al-Bantani dalam Kitab \\ ‘Uqūdullujain tentang Konsep Kesetaraan}

Seperti diketahui, Syekh Nawawi menulis Kitab Sharah 'Uqüdullujain sekitar tahun $1294 \mathrm{H}$, sekitar beliau berusia kurang lebih 64 tahun. Sudah lebih dari satu abad yang lalu. ${ }^{66}$ Kitab 'Uqüdullujain ditulis berdasarkan sistematika penulisan tematis dimana pembahasan disusun berdasarkan tema tertentu yang dalam hal ini berkaitan dengan tema seputar hak dan kewajiban suami istri dalam keluarga. Kitab ini terdiri dari beberapa fașal kemudian diikuti dengan kajian lebih lanjut.

Sharah secara istilah berasal dari Bahasa Arab. Mensyarahi berarti menerangkan, membukukan, menjelaskan, atau melapangkan sesuatu. Mensyarahi hampir sama

\footnotetext{
63 M. Quraish Shihab, M, Quraish Shihab Menjawab 101 Soal Perempuan Yang Patut Anda Ketahui, (Jakarta: Penerbit Lentera Hati, 2011), 61.

64 Forum Kajian Kitab Kuning (Fk3), Wajah Baru Relasi Suami Istri Telaah Kitab 'Uqūdullujain, 135.

65 Mufidah, Psikologi Keluarga Islam Berwawasan Gender (Edisi Revisi), 145.

66 Forum Kajian Kitab Kuning (Fk3), Wajah Baru Relasi Suami Istri Telaah Kitab Uqūdullijain, Xi.
} 


\section{6 | Argumentasi Syekh Nawawi bin Umar Al-Bantani}

dengan memberi penjelasan dan catatan kaki. ${ }^{67}$ Jadi dapat dikatakan bahwa kitab 'Uqüdullujain ini merupakan penjelasan dari pendapat-pendapat ulama terdahulu yang dihimpun dalam sebuah kitab.

Berdasarkan hasil takhrij yang dilakukan oleh Forum Kajian Kitab Kuning (FK3) bahwa hadis-hadis yang ditulis oleh Syekh Nawawi dalam kitab 'Uqüdullujain banyak yang ditemukan hadis dari sudut sanad dinilai sempurna (șahịh) dan baik (hasan), namun lebih banyak juga hadis yang dinilai tidak shahih ada yang sanadnya lemah (ḍa'îf), lemah sekali (ḍa'îf jiddan), dan tidak memiliki rujukan yang mendukung, bahkan ada yang palsu $\left(\right.$ maud $\left.u^{\prime}\right) .{ }^{68}$

Dari uraian pada bab sebelumnya, dapat diketahui bahwa metode istidlāl yang digunakan Syekh Nawawi dalam argumennya mengenai konsep kesetaraan perempuan dalam keluarga pada kitab 'Uqüdullujain adalah berdasarkan dengan mengutip hadith-hadith yang terdapat dalam kitab-kitab terdahulu. Tetapi beliau sering kali tidak menyebutkan kualitas hadits yang digunakan sebagai dasar pendapatnya sehingga tidak semua argumen Syekh Nawawi dalam kitab 'Uqüdullujain ini dapat dijadikan sebagai sumber hukum.

Selain mengutip hadith - hadith, beliau juga menambahkan cerita hikayat masa lalu seputar kehidupan rumah tangga yang digunakan sebagai mempertegas dari suatu hadits atau landasan dari argumennya. Kisah-kisah yang disebutkan dalam kitab 'Uqūdullujain ini banyak yang mengandung unsur diskriminatif terhadap kaum perempuan. Hal ini terlihat pada pembahasan mengenai fasal yang membahas mengenai hak dan kewajiban istri lebih banyak dibahas dalam kitab ini, yaitu lebih banyak 3 halaman dari hak dan kewajiban suami terhadap istri yang hanya dibahas dalam 4 halaman.

Dasar pemikiran beliau juga dipengaruhi oleh kondisi sosial masyarakat disekitar beliau pada saat itu. Dimana perempuan pada masa itu masih dipengaruhi oleh tradisi-tradisi masa jahiliyyah perempuan tidak memiliki kebebasan bahkan untuk dirinya sendiri. Hal ini tentunya masih lumprah terjadi di sekitar beliau mengingat Kitab 'Uqüdullujain dikarang sudah lebih dari satu abad yang lalu.

Beberapa argumen Syekh Nawawi dalam kitab ‘Uqüdullujain khusunya yang berkaitan dengan kesetaraan perempuan dalam keluarga bahkan ada yang tidak mencantumkan landasan maupun keterangan yang lebih lanjut. Seperti halnya beliau secara jelas menyebutkan bahwa perempuan layaknya seorang budak:

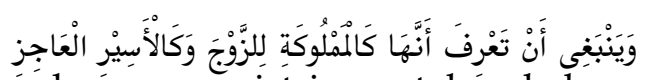

Artinya: "Dan hendaknya suami mengupayakan agar istrinya tahú bahwa sesungguhnya ia tak lebih bagaikan hamba sahaya (budak) bagi suaminya, dan seperti seorang tawanan yang tidak berdaya"

67 Samsul Munir Amin, Sayyid Ulama Hijaz Biografi Syaikh Nawawi Al-Bantani, 66.

68 Forum Kajian Kitab Kuning (Fk3), Wajah Baru Relasi Suami Istri Telaah Kitab Uqūdullijain, Xxiii. 


\section{Argumentasi Syekh Nawawi bin Umar Al-Bantani | 77}

Kutipan diatas terdapat dalam pasal 2 kitab 'Uqüdullujain yang berisi tentang hak-hak suami terhadap istri. Dalam pendapatnya, Syekh Nawawi tidak menyebutkan dalil-dalil Al-Qur'an maupun hadith yang digunakan sebagai dasar pendapatnya. Selanjutnya beliau juga berpendapat bahwa istri tidak boleh menggunakan harta suami tanpa izin darinya. Bahkan menurut pendapat mayoritas ulama, meskipun harta tersebut adalah milik pribadi istri, tetap saja istri harus memperoleh izin suaminya terlebih dahulu apabila akan menggunakan hartanya. ${ }^{69}$ Tetapi pendapat ini juga tidak mencantumkan nash-nash Al-Qur' an maupun hadìth sebagai dasarnya.

Menurut KH Husein Muhammad, Syekh Nawawi tidak menyebutkan penilaian pada suatu hadith dikarenakan memang tujuan dari dikarangnya kitab 'Uqüdullujain adalah sebagai petunjuk praktis mengenai hak dan kewajiban bagi suami istri dalam mengarungi bahtera rumah tangga sesuai dengan ajaran agama Islam. ${ }^{70}$ Oleh karena itu apabila beliau Syekh Nawawi juga menyebutkan mengenai penilaian hadith dapat mengurangi urgensi dari tujuan dikarangnya kitab ‘Uqūdullujain ini.

Pendapat dan fatwa beliau telah banyak di adopsi ke dalam hukum perkawinan di Indonesia. Namun, mengingat adanya kondisi dan perkembangan zaman, dalam Undang-Undang Perkawinan telah dilakukan beberapa kodifikasi yang lebih mendukung relasi gender yang adil dalam perkawinan. Meskipun dalam beberapa pasal dalam Undang-Undang masih menampakkan adanya dualisme tugas dan kedudukan perempuan dalam keluarga.

\section{PENUTUP}

Berdasarkan hasil pembahasan di atas dapat disimpulkan; pertama, argumen Syeh Nawawi dalam Kitab 'Uqūdullujain tentang kesetaraan perempuan dalam keluarga dilihat dari kacamata gender bahwa pemikiran beliau dinilai lebih memposisikan perempuan pada posisi melayani laki-laki, dan menampilkan beberapa teks yang cenderung merendahkan kaum perempuan. Ruang gerak perempuan pada masa itu dibatasi bahkan dalam pergaulannya kepada suami. Tampak jelas pada beberapa penjelasan dalam kitab ini yang menyebutkan berbagai larangan bagi perempuan dalam hal pergaulan dalam rumah tangga. Hal ini karena dipengaruhi budaya setting pada masa itu. Kedua, Dasar pemikiran Syekh Nawawi dalam Kitab 'Uqūdullujain adalah dengan menggunakan metode penukilan dari pendapat ulama-ulama sebelumnya yang sudah dibukukan dalam beberapa kitab. Beliau dalam pendapatnya menukil pada hadith - hadith yang berkaitan dengan materi yang dibahas yaitu berkiatan dengan kedudukan perempuan dalam keluarga. Selain itu beliau juga menambahkan beberapa cerita hikayat masa lalu yang dijadikan sebagai dasar argumennya maupun sebagai penjelas. Tetapi ada juga beberapa argumen beliau yang tidak mencantumkan

69 Syekh Muhammad Bin Umar An-Nawawi, Keharmonisan Rumah Tangga Terjemahan Syarah 'Uqūdullujain, 46.

70 Husein Muhammad, Islam Agama Ramah Perempuan, 201. 


\section{8 | Argumentasi Syekh Nawawi bin Umar Al-Bantani}

dasar yang digunakan baik dari Al-Qur'an maupun hadith, sehingga tidak semua argumemen beliau dapat dijadikan sebagai sumber hukum.

\section{DAFTAR PUSTAKA}

Amin, Samsul Munir. 2008. Karomah Para Kiayi. Yogyakarta: Pustaka Pesantren.

-------- 2009. Sayyid Ulama Hijaz Biografi Syaikh Nawawi Al-Bantani. Yogyakarta: Pustaka Pesantrean.

Amiruddin, Zen. 2009. Ushul Fiqih. Yogyakarta: Sukses Offset.

An-Nawawi, Syekh Muhammad bin Umar. 2011. Keharmonisan Rumah Tangga, terj. Ali Maghfur Syadzili Iskandar. Surabaya: Al-Miftah.

Anshary. 2010. Hukum Perkawinan di Indonesia. Yogyakarta: Pustaka Pelajar.

Anshori dan Abdul Ghofur. 2011. Hukum Perkawinan Islam Perspektif Fiqih dan Hukum Positif. Yogyakarta: UII Press.

Bustomi, Afif dan Mansyuri Ikhwan. 2000. Etika Berumah Tangga. Jakarta: Pustaka Setia.

Dhofier, Zamakhsari. 1982. Tradisi Pesantren. Jakarta: LP3ES.

Djamil, Abdul. 2002. Bias Jender Dalam Pemahaman Islam. Yogyakarta: Penerbit Gama Media.

Fuadi, Afnan. 2020. Keragaman Dalam Dinamika Sosial Budaya Kompetensi Sosial Kultural Perekat Bangsa. Sleman: CV Budi Utama.

Forum Kajian Kitab Kuning (FK3). 2001. Wajah Baru Relasi Suami Istri Telaah Kitab ‘Uqūdullujain. Yogyakarta: LkiS Yogyakarta.

Ghony, M. Junaidi \& Fauzan Al-Manshur. 2012. Metode Penelitian Kualitatif Edisi Revisi. Yogyakarta: Ar-Ruzz Media.

Hadikusuma, Hilman. 2007. Hukum Perkawinan Indonesia. Bandung: Anggota Ikapi.

Hadi, Sutrisno. 1990. Metodologi Research. Yogyakarta: Andi Offset.

Hermawan, Iwan. 2019. Ushul Figh Metode Kajian Hukum Islam. Kuningan: Hidayatul Quran.

Isnaini, Putri. 2017. Hak dan Kewajiban Suami Isteri (Studi Komparasi Hukum Positif dan Pemikiran Syekh Muhammad Nawawi Al-Bantani Dalam Kitab ‘Uqūdullujain fī Bayāni Ḥuqūqu Zaujain. Skripsi. Salatiga: IAIN Salatiga. 


\section{Argumentasi Syekh Nawawi bin Umar Al-Bantani | 79}

Istibsyaroh. 2004. Hak-Hak Perempuan Relasi Jender Menurut Tafsir Al-Sya'rawi. Jakarta: Penerbit Teraju.

Jayanthi, Evi Tri, “Faktor-Faktor Penyebab Terjadinya Kekerasan Dalam Rumah Tangga Pada Survivor Yang Ditangani Oleh Lembaga Sahabat Perempuan Magelang," Dimensia, Volume 3, No. 2, September 2009, 33: Baca Juga Mery Ramadani1 Dan Fitri Yuliani, “Kekerasan Dalam Rumah Tangga (Kdrt) Sebagai Salah Satu Isu Kesehatan Masyarakat Secara Global," Jurnal Kesehatan Masyarakat Andalas Program Studi Kesehatan Masyarakat Fakultas Kesehatan Masyarakat Universitas Andalas, (2), 2015: 80-87.

Khasanah, Lutfiatul. 2016. Hak dan Kewajiban Suami Istri Dalam Kitab ‘Uqūdullujain dan Undang-Undang Nomor 1 Tahun 1974 Tentang Perkawinan. Skripsi. Kediri: STAIN Kediri.

Kholilurrohman. 2018. Menelusuri Distorsi Dalam Ilmu Kalam. Tangerang: Nurul Hikmah Press.

Mas'udi, Masdar F. 1997. Islam dan Hak-Hak Reproduksi Perempuan. Bandung: Anggota Ikapi.

Maulidia, Rohmah. 2021. "The Implementation Of Presidential Decree On Gender Mainstreaming: Insights From IAIN Ponorogo," Justicia Islamica: Jurnal Kajian Hukum Dan Sosial, 149 Vol.18, No. 1.

-, 2015. Kontribusi Pesantren pada MDGs. Surabaya: Imtiyaz:

Misno, Abdurrahman dan Nurhadi. 2020. Ilmu Ushul Figh Dari Arabia Hingga Nusantara. Bandung: Media Sains Indonesia.

Moleong, Lexy J. 2010. Metodologi Penelitian Kualitatif. Bandung: PT Remaja Rosdakarya.

Mufidah. 2014. Psikologi Keluarga Islam Berwawasan Gender (Edisi Revisi). Malang: UIN Maliki Press.

Muhammad, Husein. 2002. Fiqh perempuan. Yogyakarta: IRCisoD Yogyakarta. 2021. Islam Agama Ramah Perempuan. Yogyakarta: IRCisoD Yogyakarta.

Mulia, Siti Musdah. 2011. Muslimah Sejati Menempuh Jalan Islami Meraih Ridha Ilahi. Bandung: Penerbit Marja.

Nasri, Ulyan. 2015. Akar Historis Pendidikan Perempuan Refleksi Pemikiran TGKH. M. Zainuddin Abdul Madjid. Yogyakarta: CV Budi Utama.

Puspitawati, Herien dkk. 2019. Mewujudkan Pendidikan Adil Gender di Keluarga dan Sekolah. Bogor: PT Pernerbit IPB Press. 


\section{Argumentasi Syekh Nawawi bin Umar Al-Bantani}

Sabiq, Sayyid. 2017. Fiqih Sunnah, terj. Muhammad Nasiruddin Al-Albani. Jakarta: Cakrawala Publishing.

Sanjaya, Umar Haris dan Aunur Rahim Faqih. 2017. Hukum Perkawinan Islam. Yogyakarta: Gama Media.

Shihab, M. Quraish. 2011. M, Quraish Shihab Menjawab 101 Soal Perempuan Yang Patut Anda Ketahui. Jakarta: Penerbit Lentera Hati.

Sugiyono. 2016. Metode Penelitian Kuantitatif, Kualitatif, dan RED. Bandung: Alfabeta.

Sukerti, Ni Nyoman dan I. GST. Ayu Agung Ariani. 2016. Buku Ajar Gender Dalam Hukum. Denpasar: Pustaka Ekspresi.

Suprihatini, Amin. 2008. Perlindungan Terhadap Anak. Klaten: Cempaka Putih.

Surahman Dkk. 2016. Metodologi Penelitian. Jakarta: (t.p.).

Syatibi, Ahmad. 2004. Jejak Syekh Nawawi al-Bantani. Banten: Harian Fajar Banten.

Undang-Undang No. 16 tahun 2019 tentang Perkawinan.

Usman, Rachmadi. 2006. Aspek-Aspek Hukum Perorangan dan Kekeluargaan di Indonesia. Jakarta: Sinar Frafika.

Yasin. 2007. Melacak Pemikiran Syaikh Nawawi Al-Bantani. Semarang: RaSAIL Media Group. cetakan 1.

Zed, Mestika. 2008. Metode Penelitian Kepustakaan. Jakarta: Yayasan Obor Indonesia.

Choeri, Imron dan Dliyaul Adlha. 2019. “Komparasi Konsep Pemenuhan Hak dan Kewajiban Suami Istri Dalam Kitab 'Uqūdullujain fī Bayāni Ḥuqūqu Zaujain dan Kitab Manba' Al-Sa'ādah”. Jurnal Studi Hukum Islam. Vol. 6. 1. 50-84.

Fatah, Ahmad. 2014. "Mendambakan Paradigma Kesetaraan Dalam Pernikahan (Telaah Kritis terhadap Kitab 'Uqūdullujain)”. Jurnal Penelitian. Vol. 8. 2. 339362.

Harun AR, Mariatul Qibtiyah. 2015. "Rethingking Peran Perempuan Dalam Keluarga." KARSA. Vol. 23. 18-35.

Jufri, Muhammad dan Rizal Jufri. 2019. “Hak dan Kewajiban Istri yang Berkarier: Studi Komparatif Antara Kitab 'Uqūdullujain dan Kitab Fikih Wanita Yusuf Qardhawi". Jurnal Istidlal Vol. 3. 1. 57-80.

Saidah. 2017. "Kedudukan Perempuan dalam Perkawinan (Analisis UU RI No. 1 Tahun 1974 Tentang Posisi Perempuan). Jurnal Al-Maissyah. Vol. 10. 2. 292-312. 
Argumentasi Syekh Nawawi bin Umar Al-Bantani | 81

Sanusi, Ahmad. 2015. “Pemikiran Nawawi Al Bantani Tentang Munakahat dan Relasi Gender". ALQALAM. Vol. 32. 144-166.

Suwarjin. 2017. "Biografi Intelektual Syekh Nawawi Al-Bantani”. Tsaqofah Tarikh. Vol. 2. $190-202$.

Rahmawaty, Anita. 2015. "Harmoni Dalam Keluarga Perempuan Karir: Upaya Mewujudkan Kesetaraan dan Keadilan Gender". PALASTREN. Vol. 8. 1. 1-35.

Gaffar Hasan, Abdul. "Hak dan Kewajiban Wanita dalam Islam," terj. Ummu Abdillah al-Buthoniyah dalam http://www.raudhatulmuhibbin.org. (diunduh pada tanggl 17 Desember 2020).

http://www.academia.edu/18411801/Istidlal?auto=download (dikses pada hari Sabtu, 6 Maret 2021 pukul 20:05)

Https:/ /Nasional.Tempo.Co/Read/1439271/Komnas-Perempuan-Ada-299-911Kasus-Kekerasan-Terhadap-Perempuan-Sepanjang-2020/Full\&View=Ok/

Https:/ / Komnasperempuan.Go.Id/Siaran-Pers-Detail/Catahu-2020-KomnasPerempuan-Lembar-Fakta-Dan-Poin-Kunci-5-Maret-2020/ 